Journal of Mathematics and Informatics

Vol. 17, 2019, 9-19

ISSN: 2349-0632 (P), 2349-0640 (online)

Published 26 May 2019

www.researchmathsci.org

DOI: http://dx.doi.org/10.22457/jmi.146av17a2

Journal of

Mathematics and

Informatics

\title{
Impact of Overseas Backgrounds of Top Management Team on firm performance: Based on Chinese Information Technology Industry
}

\author{
Li Cui \\ School of Economics and Management \\ Chongqing University of Posts and Telecommunications \\ Chongqing, 400065, China. Email: 451417524@qq.com \\ No.2, Chongwen Road, Nan'an District, Chongqing, China, 400065
}

Received 26 April 2019; accepted 24 May 2019

\begin{abstract}
As the domestic market competition continues to intensify, the active implementation of the "going out" strategy has become an important way for companies to seek new sources of profit growth and gain market share. However, although the export and foreign direct investment have continued to accelerate in recent years in our country, there are still many problems in the process of internationalization. The executives' decision-makers lack understanding of internationalization and leadership. This thesis will explore whether we can enhance overall performance of the executive team through enhancing the overseas background of the top management team (including overseas study background, overseas work background and foreign executives) from the perspective of direct acquisition of international knowledge and skills. In terms of research content, based on the 2011-2016 panel data of 185 Chinese ICT industry listed companies, this thesis focuses on the relationship between the overseas study background, the overseas work background of the top management team, and the proportion of foreign members short-term performance and long-term performance of the company.
\end{abstract}

Keywords: top management team, overseas background, internationalization, firm performance

AMS Mathematics Subject Classification (2010): 90B50

\section{Introduction}

Along with the intensification of competition in the domestic market, the profit margin of enterprises has been continuously squeezed, and the active implementation of the "going out" strategy has become an important way for enterprises to seek new sources of profit growth. As the national strategic industrial sector and the main position of technological innovation, the ICT industry is also adopting a series of strategic measures to expand the international market. These measures not only promote the development and progress of the entire industry, but also drive the rapid growth of a group of enterprises in the 
industry. Many companies' technology research and development achievements and product innovations have been greatly improved. For example, Huawei's 5G communication technology, Haier's smart home appliances and IoT business related patents all occupy international leading position, Huawei, Lenovo, Tencent and other more than 10 ICT companies.For several consecutive years, it is at the forefront of China's top 100 multinational companies. In the world's Internet market capitalization rankings, Alibaba, Baidu and Tencent rank among the top ten. However, although the export and foreign direct investment of Chinese enterprises have continued to accelerate in recent years, it is undeniable that enterprises still have many problems in the process of internationalization, such as a single form of investment and high risks, slow growth of overseas performance levels, and successful entry into developed countries. The number of companies is limited, the company's internationalization strategy and the path of innovation are ambiguous, and executives' decision-makers lack understanding of internationalization and leadership [1-2]. If Chinese enterprises want to improve their internationalization level, they must not only start from the internationalization strategy, but also pay attention to the selection of senior executives and the configuration of senior management team members. In today's market competition, they will drive the nationalization level of enterprises. The key factors for the improvement are the overseas background and international experience of the senior management team; in the face of market uncertainty, executives with overseas experience and international experience are better able to strategize, and their understanding of overseas markets is deeper, thus A more positive response to the global strategic format [3-4].

\section{Literature review}

Hambrick and Mason [5] formally proposed a high-order theory in the paper "High-level: Organization as a reflection of top management", which holds that executives play a major role in business organization, they determine the company's strategic direction and Various major decisions. The decision-making behavior of executives is influenced by a series of personal traits such as cognitive style, world outlook and experience accumulated over a long period of time. In the high-order theory [5,6], the overall characteristics of the executive team contribute much more to organizational performance than individuals. However, in the existing literature research, the definition of executive team members is not uniform, and the differences in research purposes and data availability are different for the definition of executive members. In 1996, Amason [7] defined executive team members as managers involved in decision-making in his paper "Resolving Conflicts among Executive Teams". Abraham and John et al. [8-9] considered executive teams to include chiefs. Executive Officer, Chief Operating Officer, Chief Financial Officer and Vice President; Christophe and Walter [10] formed an executive team with executives identified by the CEO to participate in strategic decision making; domestic scholar Ping [11] and Yuanqiong In the study of the senior management team, Hao [12] formed a senior management team among the senior management personnel of the company, and the staff of the various functional departments formed a senior management team. Haifan [13] expanded on the basis of previous studies. The president, vice president, board of supervisors, board of directors and other important personnel involved in decision-making. The executive team consisting of multiple senior decisionmakers should be at least a team, but this is often overlooked by researchers [14]. Foreign 
Impact of Overseas Backgrounds of Top Management Team on firm performance: Based
on Chinese Information Technology Industry

research Carpenter [15] proposed a true executive team in the 2003 study: the division of labor among members should be clear, each member should have a clear goal for their division of labor, and the trust between members is essential and guaranteed. Information sharing, responsibility and risk are taken together; the real executive team is the owner of decision-making and control of the enterprise, not only needs to participate in the formulation of corporate strategy, but also be loyal to the organization. The corporate executive team is responsible for corporate strategy development and final decisionmaking. The executive team not only affects the organization's development, but also affects corporate performance. The executive team is a small group of senior executives, generally including the chairman of the board, vice chairman, chief executive officer, chief operating officer, president, senior vice president, executive vice president, and senior general manager who reports directly to them; This paper summarizes the previous definitions of senior management team and the research data of the characteristics of Guotaian listed companies. The senior management team includes not only senior management personnel, but also important senior management personnel who make decision-making, such as corporate board members and members of the board of supervisors.

\section{The model}

\subsection{Proposal of research hypothesis}

The overseas background of executives is simply summarized as executives with overseas study and work experience. As one of the special characteristics of executives, overseas background is not only a special life experience for executives, but also enriches the experience of senior executives. The impact collision of cultural and historical backgrounds gives executives more knowledge and a newer management perspective [16]. Considering that the definition of the existing overseas background is not clear, this paper refers to the definition of international experience by Herrmann and Datta [17] on the basis of the definition of international exposure by foreign scholar Lee and Park [18]. In combination with the definition of Haiguigui entrepreneurs in Liu et al. [19], and considering the internationalization of China, there are certain differences in the cultural and historical background between Hong Kong, Macao and Taiwan and the mainland (Mainland). Including studying and working experience in Hong Kong, Macao and Taiwan [20]; overseas background is not necessarily obtained through overseas field study and work experience. Foreign household registration can also understand overseas society, history and culture, so this article is based on predecessors. The overseas background is defined as the following three types: having foreign nationality or permanent residence in Hong Kong, Macao and Taiwan, having educational experience abroad or in Hong Kong, Macao and Taiwan, or having experience in working in Hong Kong, Macao and Taiwan regions or outside China [21].

Based on the above analysis, the following research hypotheses 3.1 and 3.2 are proposed:

H 3.1: The overseas background of the executive team is positively affecting the longterm performance of the company. Specifically, the stronger the overseas study background of the senior management team, the higher the long-term performance level 
of the company; the stronger the overseas work background of the senior management team, the higher the long-term performance level of the enterprise; the stronger the background of the overseas members of the senior management team, the long-term performance level of the enterprise the higher.

H 3.2: The overseas background of the executive team is positively affecting the shortterm performance of the company. Specifically, the stronger the overseas study background of the senior management team, the higher the short-term performance level of the enterprise; the stronger the overseas work background of the senior management team, the higher the short-term performance level of the enterprise; the stronger the background of the overseas members of the senior management team, the short-term performance level of the enterprise the higher.

International companies make strategic moderations based on changes in internal and external environments. Etgar and Rachman [22] empirically analyzed that the failure of the moderation of the internationalization strategy of retail enterprises was mainly due to the mistakes made by managers and the lack of coordination of work. In the study of the relationship between internationalization level and corporate performance, foreign scholars Errunz and Senbet 23], Delios and Beamish [24], Grant [25] and others hold the same view, that is, the higher the level of internationalization, the executives will have deeper the understanding of overseas, the faster and more accurate countermeasures for the overseas changing market, and thus the improvement of corporate financial performance. When studying with the example of "born globalization", Zhou [26] and others considered that the degree of internationalization has a significant positive correlation with corporate performance. Based on the high-order theory, this paper proposes the following research hypotheses 3 and 4 :

H 3.3: The level of internationalization plays a positive moderation effect on the overseas background of the senior management team and the long-term performance of the company. The specific performance is that when the level of internationalization is high, the long-term performance of the senior management team with high overseas background is lower than that of the overseas background. Long-term performance of the company is better.

H 3.4: The level of internationalization plays a positive moderation effect on the overseas background of the senior management team and the short-term performance of the enterprise. The specific performance is that the high-level internationalization level of the senior management team has a lower short-term performance than the overseas background. Corporate short-term performance is better.

\subsection{The research model}

Based on the above research models and research hypotheses, the measurement models set in this paper are as follows. Among them, model (3.1) and model (3.2) are used to test the relationship between overseas study background, work background and foreign members' long-term performance and short-term performance. i.e. Research Hypothesis 3.1 and Hypothesis 3.2; Model (3.3.1) to Model (3.3.3) are used to test the regulatory effect of internationalization level between executives' overseas background and firm 
Impact of Overseas Backgrounds of Top Management Team on firm performance: Based on Chinese Information Technology Industry

long-term performance, ie Research Hypothesis 3.3; Model ( 3.4.1) The model (3.4.3) is used to test the moderation effect of the internationalization level between the overseas background of executives and the short-term performance of enterprises, namely the research hypothesis 3.4 .

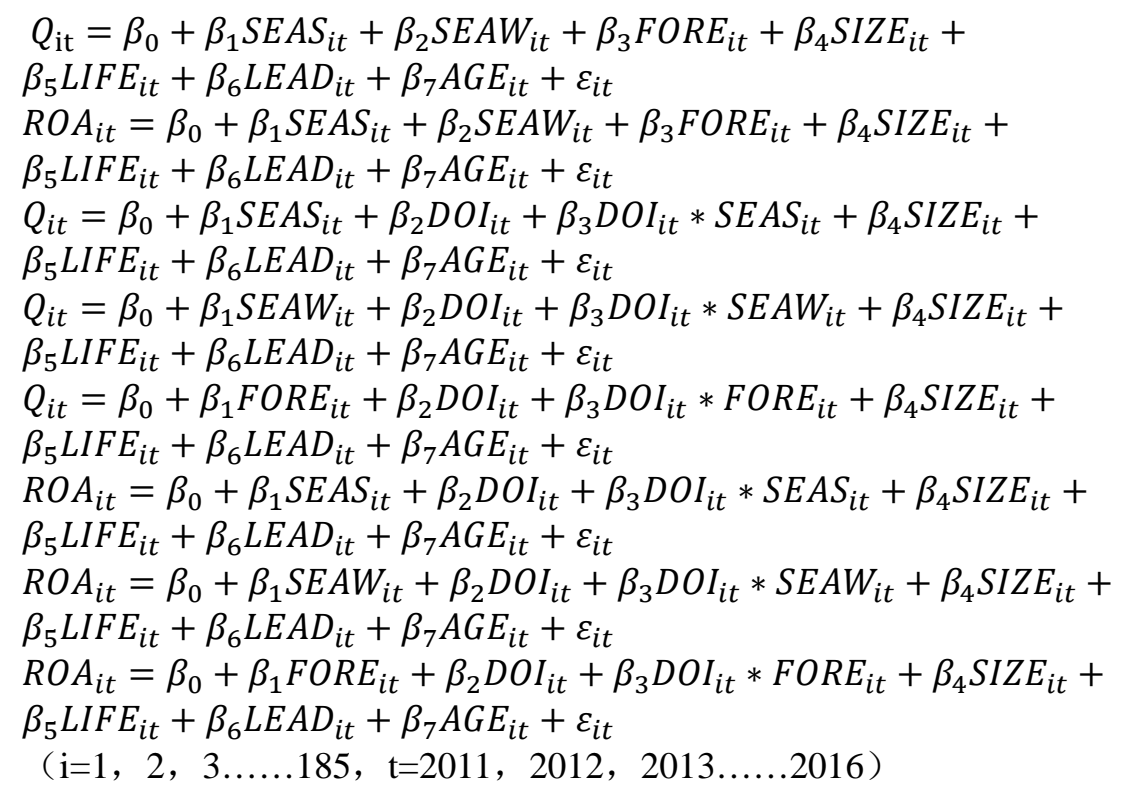

\subsection{Empirical analysis}

In order to verify the impact of the senior management team's overseas background on the long-term performance and short-term performance of the company, this paper uses the senior management team's overseas study background, overseas work background, foreign members as independent variables and the company's long-term performance and short-term performance. The variable is returned. Before the regression, this paper first carries out the multi-collinearity test on each variable in the model. Then, the cointegration test is performed on the basis of the same-order single-order data in the previous section, and then the model is tested. Finally, the minimum panel is used by EVIEWS. Return to the Multicast (Panel Least Squares).

3.3.1. TMT overseas background on corporate performance

Firstly, test the model (3.1) the impact of the overseas background of the senior management team on the long-term performance of the company. The regression results are shown in Table 3.1. The overseas study background of the executive team $\left(\beta_{1}=3.7721, P<0.01\right)$ significantly positively affects the long-term performance of the company, while The overseas work background of the team $\left(\beta_{2}=-0.2976, \mathrm{P}<0.01\right)$ and the foreign members of the senior management team $\left(\beta_{3}=-3.4237, \mathrm{P}<0.01\right)$ have a significant negative impact on the long-term performance of the company; the results of the study indicate that the senior management team overseas The positive impact of the 


\section{Li Cui}

background on the long-term performance of the firm is assumed to be verified, ie the assumption (3.1) is partially established.

Table 3.1: TMT overseas background and corporate long-term performance

\begin{tabular}{|c|c|c|c|}
\hline variable & coefficient & tvalue & Pvalue \\
\hline $\mathrm{C}$ & $20.2642 * * *$ & 70.53 & 0.0000 \\
\hline seas & $3.7721 * * *$ & 46.71 & 0.0000 \\
\hline seaw & $-0.2976 * * *$ & -3.29 & 0.0010 \\
\hline fore & $-3.4237 * * *$ & -33.10 & 0.0000 \\
\hline size & $-0.9488 * * *$ & -123.19 & 0.0000 \\
\hline life & $1.4762 * * *$ & 60.46 & 0.0000 \\
\hline lead & $-0.3182 * * *$ & -15.56 & 0.0000 \\
\hline age & 0.0205 & 0.27 & 0.7867 \\
\hline & $F$-statist & $121.64 * * *$ & $N: 1110$ \\
\hline
\end{tabular}

Note: $*, * *, * * *$ indicate statistical results at $10 \%, 5 \%, 1 \%$, respectively.

Next, test the impact of the model (3.2) on the short-term performance of the executive team's overseas background. The regression results are shown in Table 3.2. The results show that the senior management team's overseas learning background $\left(\beta \_1=0.0351\right.$, $\mathrm{P}<0.01)$, the executive team work background $\left(\beta \_2=0.0055, \mathrm{P}<0.01\right)$ significantly positively affects the short-term performance of enterprises. Foreign members ( $\beta \_3=0.0055, \mathrm{P}<0.1$ ) also positively affect the short-term performance of the company, but the significant effect is not the background and work background of the senior management team. Strong, so the regression results still indicate that the overseas background of the executive team is positively affecting the short-term performance of the company, and hypothesis (3.2) has been verified.

Table 3.2: TMT overseas background and short-term performance

\begin{tabular}{|c|c|c|c|}
\hline Variable & coefficient & tvalue & Pvalue \\
\hline $\mathrm{C}$ & $0.3342 * * *$ & 56.12 & 0.0000 \\
\hline Seas & $0.0351 * * *$ & 20.97 & 0.0000 \\
\hline Seaw & $0.0055^{* * *}$ & 2.92 & 0.0034 \\
\hline Fore & $0.0039 *$ & 1.84 & 0.0660 \\
\hline Size & $0.0025^{* * *}$ & 15.56 & 0.0000 \\
\hline Life & $-0.0389 * * *$ & -76.94 & 0.0000 \\
\hline Lead & $0.0143 * * *$ & 33.78 & 0.0000 \\
\hline Age & $-0.0691 * * *$ & -43.97 & 0.0000 \\
\hline$R^{2}: 0.05$ & F-statistic: $54.73^{* *}$ & $N: 1110$ & \\
\hline
\end{tabular}

In summary, the results of the test hypothesis H3.1 and H3.2 are shown in the following table. 
Impact of Overseas Backgrounds of Top Management Team on firm performance: Based on Chinese Information Technology Industry

Table 3.3: The results of $\mathrm{H} 3.1-\mathrm{H} 3.2$

\begin{tabular}{llll}
\hline Hypothesis & results & notes \\
\hline $\begin{array}{l}\text { H 3.1: The overseas background of TMT is } \\
\text { positively affecting the long-term }\end{array}$ & $\begin{array}{l}\text { Partial seaw and fore negatively } \\
\text { support }\end{array}$ & $\begin{array}{l}\text { affect the long-term } \\
\text { performance }\end{array}$ \\
$\begin{array}{l}\text { H 3.2: The overseas background of TMT is } \\
\text { positively affecting the short-term support enterprises }\end{array}$ \\
performance
\end{tabular}

3.3.2. Moderation effect test

In order to further test the influence mechanism of the level of internationalization in the causal relationship between the overseas background of the senior management team and the long-term and short-term performance of the enterprise; this section uses the level of internationalization of the enterprise as a moderator to study overseas background of the TMT and long-term and short-term performance.

Models (3.3.1), (3.3.2), and (3.3.3) in table 3.4tested the moderation effect of DOI in the relationship between top management team oversea backgrounds and long-term performance ( $\mathrm{Q}$ value) of companies. Th results show that there are significant negative moderating role, which is just opposite with our hypothesis H3.3. Models (3.4.1), (3.4.2), and (3.4.3) in table 3.5tested the moderation effect of DOI in the relationship between top management team oversea backgrounds and short-term performance (ROA) of companies. The results show that the moderation effect is negative in the causal relationship between top management team oversea study background and ROA, as well as in the relationship between oversea member ratio and ROA, but the moderation effect is positive in the relationship between oversea work background and ROA.

Table 3.4: The moderation effect of DOI on long-term performance ( $Q$ value)

\begin{tabular}{|c|c|c|c|}
\hline & Model (3.3.1) & Model (3.3.2) & Model (3.3.3) \\
\hline variable & coefficient & coefficient & coefficient \\
\hline $\mathrm{C}$ & $19.4819 * * *$ & $20.4939 * * *$ & $19.8793 * * *$ \\
\hline SIZE & $-0.9683^{* * *}$ & $-1.0066 * * *$ & $-0.9433 * * *$ \\
\hline LIFE & $1.5719 * * *$ & $1.6249 * * *$ & $1.5640 * *$ \\
\hline LEAD & $-0.2987 * * *$ & $-0.2683 * * *$ & $-0.4572 * * *$ \\
\hline AGE & $0.2084 * * *$ & $0.1624 * *$ & 0.1189 \\
\hline DOI & $1.2417 * * *$ & $0.6154 * * *$ & $0.2625^{* * *}$ \\
\hline SEAS & $7.4995 * * *$ & & \\
\hline SEAS*DOI & $-20.4356^{* * *}$ & & \\
\hline SEAW & & 2.9016 *** & \\
\hline SEAW*DOI & & $-11.6380 * * *$ & \\
\hline FORE & & & $6.5389^{* * *}$ \\
\hline FORE*DOI & & & $-12.6975^{* * *}$ \\
\hline$R^{2}$ & 0.13 & 0.10 & 0.10 \\
\hline
\end{tabular}


Li Cui

\begin{tabular}{cccc}
\hline & Model (3.3.1) & Model (3.3.2) & Model (3.3.3) \\
\hline variable & coefficient & coefficient & coefficient \\
$F$-statistic & $153.77^{* * *}$ & $117.71 * * *$ & $153.77 * * *$ \\
$N$ & 1110 & 1110 & 1110 \\
\hline
\end{tabular}

Table 3.5: The moderation effect of DOI onshort-term performance (ROA)

\begin{tabular}{cccc}
\hline & Model $(3.4 .1)$ & Model $(3.4 .2)$ & Model $(3.4 .3)$ \\
\hline variable & coefficient & coefficient & coefficient \\
C & $0.3308^{* * *}$ & $0.3520^{* * *}$ & $0.3316^{* * * *}$ \\
SIZE & $0.0029^{* * *}$ & $0.0028^{* * *}$ & $0.0033^{* * * *}$ \\
LIFE & $-0.0369^{* * *}$ & $-0.0379^{* * *}$ & $-0.0360^{* * * *}$ \\
LEAD & $0.0132^{* * *}$ & $0.0137 * * *$ & $0.0097 * * *$ \\
AGE & $-0.0711^{* * *}$ & $-0.0752^{* * *}$ & $-0.0720^{* * * *}$ \\
DOI & $-0.0135^{* * *}$ & $-0.0255^{* * *}$ & $-0.0163 * * *$ \\
SEAS & $0.0718^{* * *}$ & & \\
SEAS*DOI & $-0.1048^{* * *}$ & & \\
SEAW & & $0.0124 * * *$ & \\
SEAW*DOI & & $0.0849^{* * *}$ & \\
FORE & & & $0.2464 * * *$ \\
FORE*DOI & & 0.05 & $-0.3230^{* * *}$ \\
$R^{2}$ & 0.05 & $56.50^{* * * *}$ & 0.06 \\
F-statistic & $61.48^{* * *}$ & 1110 & $67.92^{* * *}$ \\
$N$ & 1110 & & 1110 \\
\hline
\end{tabular}

Table 3.6: The results of $\mathrm{H} 3.3-\mathrm{H} 3.4$

\begin{tabular}{ll}
\hline Hypothesis & results \\
\hline H3.3:The level of internationalization plays a \\
positive moderation effect on the overseas & Not \\
background of the senior management team and the & support \\
long-term performance of the company. & \\
$\begin{array}{l}\text { H3.4: The level of internationalization plays a } \\
\text { positive moderation effect on the overseas }\end{array}$ & Partial \\
background of the senior management team and the & support \\
short-term performance of the company. & \\
\hline
\end{tabular}

\section{Conclusion and discussion}

Based on the high-order theory, this paper studies the panel data of 185 companies with a sample capacity of 1110 in China's information technology industry from 2011 to 2016, and studies the impact of the overseas background of the executive team on the long-term performance and short-term performance of the company. As a moderator, the level of regulation explores the regulatory effect of the level of internationalization of firms on the overseas background of executive teams and the long-term and short-term 
Impact of Overseas Backgrounds of Top Management Team on firm performance: Based on Chinese Information Technology Industry

performance of firms. Based on the relevant regression results, the paper has obtained the following conclusions:

(1) The overseas background of the senior management team is positively affecting the short-term performance of the company, and negatively affects the long-term performance of the enterprise;

(2) The level of internationalization has a significant regulatory effect on the overseas background of executive teams and the causal relationship between firm and short-term performance, and has different effects on the relationship between different executive backgrounds and long-term and short-term performance relationships;

(3) The relationship between the overseas background of executive teams and the longterm and short-term performance of enterprises has significant differences between equipment manufacturing and service industries. In China's equipment manufacturing industry, the background of overseas work of executive teams is positively affecting long-term performance and short-term performance. The senior executives in the background of foreign members negatively affect the long-term performance and shortterm performance of the company; the background of overseas study of the senior management team negatively affects the short-term performance of the enterprise, but the relationship with the long-term performance of the enterprise is not significant. In contrast, in the information service industry, the overseas study background of the executive team is positively affecting the long-term performance and short-term performance of the company; the relationship between the background of the senior management team and the long-term performance of the company is not significant, and the impact on short-term performance is negative. As with equipment manufacturing, the impact of foreign members on long-term performance and short-term performance of the company is negative;

(4) In the overseas background of executive teams and the causal relationship between firm and short-term performance, there is a significant difference in the regulatory role of internationalization in equipment manufacturing and information services. The relationship between the overseas background of the senior management team and the long-term performance of the company:

In the equipment manufacturing industry, with the continuous improvement of the internationalization level, the overseas study background of the senior management team and the negative influence of foreign members on the long-term performance of the enterprise are gradually weakened, and the level of internationalization is constantly Ascension, the value of the overseas work background of the executive team on the longterm performance of the company continues to weaken. In the information service industry, the continuous improvement of the internationalization level has weakened the value of the overseas study background of the senior management team in the long-term performance of the company. On the contrary, the overseas work background of the senior management team and the value of foreign members in the long-term performance of the enterprise are constantly emerging. The relationship between the overseas background of the executive team and the short-term performance of the company: In the equipment manufacturing industry, the level of internationalization has been continuously improved, which has weakened the negative impact of the overseas study background of the senior management team on the short-term performance of the company, while the 
senior management team's overseas work background has short-term performance The value of the information service industry is reduced. In the information service industry, the level of internationalization is improved. The value of the overseas study background of the senior management team is reduced, and the value of the overseas work background of the senior management team increases the value of the short-term performance of the enterprise. The negative impact of members on the short-term performance of the company.

Acknowledgement. This work is supported by The National Social Science Fund of China under Grant No.17CGL059. The author is also thankful to the reviewers for their valuable comments.

\section{REFERENCES}

1. L.Chen, J.Liu and S.Zhang, The influence of imitation isomorphism on the performance of enterprise internationalization - an empirical study based on the legitimacy of institutional theory, China Industrial Economy, 9 (2016) 127-143.

2. L.Chen, Disputes on the relationship between internationalization strategy and corporate performance: a review of international studies, Nankai Management Review, 5 (2014) 112-125.

3. Z.Yang and W.Zhang, Research on the relationship between enterprise international lization degree and performance, Economic Research, 2 (2009) 32-42.

4. M.Li and T.Yu, Overseas R\&D investment and parent company innovation performance-based on the moderation of corporate resources and internationallization experience, World Economic Research, 8 (2016) 101-113.

5. D.C.Hambrick and P.A.Mason, Upper Echelons: the organization as a reflection of its top managers, Social Science Electronic Publishing, 9(2) (1984) 193-206.

6. D.C.Hambrick, The top management team: key to strategic success, California Management Review, 30(1) (1987) 88-108.

7. A.C.Amason, Distinguishing the effects of functional and dysfunctional conflict on strategic decision making: resolving a paradox for top management teams, The Academy of Management Journal, 39(1) (1996) 123-148.

8. A.Carmeli and J.Schaubroeck, Top management team behavioral integration,decision quality, and organizational decline, Leadership Quarterly, 17(5) (2006) 441-453.

9. A.Carmeli, J.Schaubroeck and A.Tishler, How CEO empowering leadership shapes top management team processes: Implications for firm performance, The Leadership Quarterly, 22(2) (2011) 390-411.

10. C.Boone and W.Hendriks, Top management team diversity and firm performance: moderators of functional-background and locus-of-control diversity, Management Science, 55(2) (2009) 165-180.

11. P.Zhang, Empirical research on the heterogeneity of top management team and firm performance, Chinese Journal of Management, 4(4) (2007) 501-511.

12. Y.He and W.Chen, An empirical study on the relationship between executive team size and firm performance in uncertain environment-based on evidence from Chinese manufacturing listed companies, Science and Technology Management, 30(2) (2009) 123-128.

13. H.Lu, Research on the compensation gap in the top management, ceo's internal 
Impact of Overseas Backgrounds of Top Management Team on firm performance: Based on Chinese Information Technology Industry

succession opportunity and corporate performance - an empirical analysis based on tournament theory, Southern economy, 28(5) (2010) 23-32.

14. Y.Y.Kor, Experience-based top management team competence and sustained growth, Organization Science, 14(6) (2003) 707-719.

15. M.A.Carpenter, T.G.Pollock and M.M.Leary, Testing a model of reasoned risktaking: governance, the experience of principals and agents, and global strategy in high-technology IPO firms, Strategic Management Journal, 24(9) (2003) 803-820.

16. J.Tao, P.Shi and W.Duan, A review of higher-order theory research-based on crosslevel integration perspective, Science and Technology Management Research, 33(10) (2013) 224-229.

17. H.U.Lee and J.H.Park, The influence of top management team international exposure on international alliance formation, Journal of Management Studies, 45(5) (2010) 961-981.

18. P.Herrmann and D.K.Datta, Relationships between top management team characteristics and international diversification: an empirical investigation, British Journal of Management, 16(1) (2002) 69-78.

19. O.Dai and X.Liu, Returnee entrepreneurs and firm performance in Chinese hightechnology industries, International Business Review, 18(4) (2009) 373-386.

20. M.Giannetti, G.Liao and Y.U.Xiaoyun, The brain gain of corporate boards: evidence from China, The Journal of Finance, 70(4) (2015) 54-65.

21. F.Liu, J.Mo and R.Ma, Research on the influence of executive team's overseas background on enterprise innovation performance, Management Review, 29(7) (2017) 135-147.

22. M.Etgar, D.Rachman-Moore, Determinant factors of failures of international retailers in foreign markets, International Review of Retail Distribution \& Consumer Research, 33(2) (2015) 112-134.

23. V.R.Errunza and L.W.Senbet, The effects of international operations on the market value of the firm: theory and evidence, The Journal of Finance, 36(2) (1981) 17-25.

24. A.Delios and P.W.Beamish, Geographic scope, product diversification, and the corporate performance of Japanese firms, Strategic Management Journal, 20(8) (1999) 17-35.

25. R.M.Grant, Multinationality and performance among british manufacturing companies, Journal of International Business Studies, 18(3) (1987) 79-89.

26. L.Zhou, Internationalization and the performance of born-global smes: the mediating role of social networks, Journal of International Business Studies, 38(4) (2007) 673690. 